\title{
EDUCATIONAL
} TECHNOLOGY

\section{Ed Tech: Now a horse of a different colour?}

\author{
Derick Unwin \\ Educational Research and Development Unit \\ Queensland Institute of Technology
}

\begin{abstract}
Educational technology (edtech) embraces a variety of concepts, but is probably adequately characterised as pedagogic innovation in the area of media and methods. Such innovations have regularly occurred over the years, and have invariably been accompanied by extravagant claims of effectiveness and potential for change. In due course these innovations lose their momentum and cease to occupy the centre stage of education. This article attempts a brief sardonic review of edtech and suggests that at last we are coming into possession of tools which would permit the restructuring of education, so as to actually achieve aims rather than pay lip service to them. However, such outcomes will not arise out of any supposed improvement in media and methods, but through organisational and curriculum changes made possible by the advent of the microcomputer and peripherals.
\end{abstract}

Defining educational technology (edtech) is akin to defining science fiction. In both cases the 'genres' encompass such a heterogenous range of components as to make alternative titles and useful definitions unattainable. This particular issue of the Australian Journal of Educational Technology, however, is targeted on the themes of the present and future state of edtech; this is a difficult task indeed when we cannot be sure what edtech is now, and especially what it will be in 1990, or 2000.

Insofar as our concern is with the hardware of pedagogy it is clear that the current emphasis of edtech practitioners is on the use of microcomputers, and in particular on combinatory environments wherein video, audio and textual material, stored on such devices as videodiscs, CD ROMs, etc, is marshalled by the computer for the learner's edification.

When we turn our attention to actual didactic materials we find a divergence of opinion. One school of educational technologists places 
great faith in the concept of instructional design: on this view the hardware is best utilised to present a carefully constructed sequence of material, which will interactively lead the learner through to mastery, or an acceptable lesser degree of knowledge.

Unfortunately, experience has taught us that the design and construction of such highly structured materials is a long and arduous (and expensive!) undertaking. And worse still, it transpires that the end result may not be particularly successful. These and other reasons generate support for a more laissez faire approach to educational software. This regime uses the hardware either to present very straight forward items, easily constructed and installed, such as drill and practice; or to exploit the ready availability of high quality non-educational computer software such as word processors, spreadsheets and data base management systems. Thus a Lotus clone or other cheap spreadsheet can be used as a powerful tool for teaching Physics, History, etc.: indeed any subject involving logical relationships and perhaps others too. In the short term these sorts of applications seem to be the likely growth areas.

My remarks thus far are concerned with activity at what we might call the 'sharp end' of edtech. Many years ago the concept of audiovisual aids (AV) was dragged unwillingly into a forced marriage with edtech. To this day, AV continues to provide a valuable teaching resource, based upon whatever are the current cheapest and most convenient media available. Little change is foreseeable at this very fundamental level of activity: a continuing swing from film to video, a continuing reliance on reference books (CD ROM notwithstanding), slides, and other visual resources requiring simple equipment - or none at all - to bring them into use.

Turning to the longer term future of edtech, specifically the future of more elaborate instructional configurations, the reader will no doubt ponder on the qualifications of contributors to this issue of AJET; in particular, whether he can attach any great confidence in the crystal balls they rely on. My own credentials in this matter are impeccable: I have been in the business of forecasting the future of edtech for a quarter of a century (eg. Unwin, 1967; Unwin, 1980), and have invariably been proved wrong by events, or lack of events. However, as time has gone by my forecasts have been getting less wrong, and I suggest that a combination of experience and cynicism will at last considerably improve my performance.

I have referred before (Unwin, 1985) to the cyclical nature of edtech. With all the significant innovations: $16 \mathrm{~mm}$ films, Pressey machines, tape recording, programmed learning, video, CAL, - to list just a few - there has been associated a repetitious group of declaratory statements. To paraphrase: 
This innovation:

a. is, for various reasons, different in both kind and degree from all the predecessors

b. answers, at last, a very long felt need

c. will make the lot of the teacher much easier and/or rewarding. It will relieve the teacher from boring repetitive tasks, leaving her/him free to get on with other vitally important duties.

d. unlike earlier innovations, is soundly based on proven principles from some respected scientific discipline, eg. behavioural psychology, systems design, learning theory, market research, etc. etc.

e. will enhance the quality and effectiveness of learning at all levels.

Naturally, the propagandists for these innovations readily recognise that they have little to learn from the failed innovations of the past. This fortunately absolves them from literature searches and other tedious time wasting activities.

This cyclical nature of edtech would suggest that there may well be newer innovations must around the corner waiting to decouple the current microcomputer/video bandwagon. In my view this would be a misrepresentation of the nature of the computer. In a very real sense the power and capabilities of the microcomputer represent the end of the road so far as the development of educational hardware is concerned. Allied to sophisticated video storage and retrieval devices, the computer is in the classroom to stay. Future innovations will concentrate on organisation and environment, and on the curriculum. Conceivably, an enlightened curriculum positioned in an ideal learning environment, could have been successfully taught by many different media and methods, but the experiment was never conducted. Now, perhaps it will be.

The graduates of our school systems are eloquent testimony to the failure of these systems either to teach successfully or to teach the right material. The future of educational technology must lie in a transformation of educational organisation. If we teach the right things to the right students in an adequate environment we will accomplish the rightful aim of education: the fostering of individual abilities, enabling each student to play a rewarding role in society.

Specifically, how will edtech achieve such a transformation? By making unnecessary and irrelevant many of the current organisational constraints. By forcing recognition of the appalling pointlessness of much of the present curriculum. By allowing students to expand their horizons through the control of information. By showing students how the computer can put them in charge of their own learning. 
I had hoped that negative feedback from past inaccurate forecasting would have cured me of the sin of confusing what I think should happen with what I think will happen. On rereading the above remarks it would seem that the cure was not total. But at least it seems logical to take the view that the computer is not to be compared with the $16 \mathrm{~mm}$ projector say - in its impact on education. Surely the ramshackle edifice of corporate education cannot absorb the widespread use of computers, without being forced to put the house in order?

This essay commenced by comparing edtech to science fiction. One favoured theme of science fiction is that of the civilisation unaware that it is burdened by a significant disability of a cultural, mental, physical, etc., nature. Eventually something or someone puts the matter to rights. Let us hope, with confidence, that modern edtech systems will enable us at last to perceive the straitjacket of current educational practice: the microcomputer may yet prove to be a long awaited and much needed Trojan Horse.

\section{References}

Unwin, D. (1967). Foreword to Unwin, D. and Leedham, J. Aspects of Educational Technology, Methuen, London.

Unwin, D. (1980). The new world dawns, or Darien revisited. In D. Shearer (Ed.) Yearbook of the Australian Society for Educational Technology, ASET, Hawthorn.

Unwin, D. (1985). The cyclical nature of educational technology. Programmed Learning and Educational Technology, 22, 65-67.

Please cite as: Unwin, D. (1986). Ed Tech: Now a horse of a different colour? Australian Journal of Educational Technology, 2(1), 1-4.

http: / / www.ascilite.org.au/ajet/ ajet2/unwin.html 